\title{
PENGETAHUAN IBU MENGENAI MANFAAT ASI PADA BAYI
}

\author{
${ }^{1}$ Edelwina Umboh \\ ${ }^{2}$ Rocky Wilar \\ ${ }^{2}$ Max F. J. Mantik
}

\author{
${ }^{1}$ Kandidat Skripsi Fakultas Kedokteran Universitas Sam Ratulangi Manado \\ ${ }^{2}$ Bagian Ilmu Kesehatan Anak Fakultas Kedokteran Universitas Sam Ratulangi \\ Manado \\ edelwina.umboh@ymail.com
}

\begin{abstract}
Breast milk is the best food for the baby when he/she was born. Many researches prove that breast milk is the best and primary food for the baby because in the breast milk contain an antibody that the baby need to resist any kind of disease. The excellence of breast milk has been prove, however the tendency of the mother not to give an exclusive breast milk to their baby is bigger. It is influenced by some factors, such as occupation, age, and education.This studyisto know the relation between the knowledge of the mother about usefulness of the breast milk for the baby with exclusive breast milk. Type of study is a descriptive cross sectional with field survey method.There are 80 mothers that be the research subject. The result is 12 mothers has a good knowledge, 39 mothers the knowledge is enough, and 29 mothers has a less knowledge. There are 41 mothers that give an exclusive breast milk and 39 mothers that don't, there is a meaningful relation with chi - square test $(p=0.016)$.Conclusion: Where is the higher the knowledge of the mother about the usefulness of breast milk for the baby, the higher breastfeeding is success.
\end{abstract}

Keywords: Exclusive breast milk, knowledge, mother.

\begin{abstract}
Abstrak.Air susu ibu adalah makanan terbaik bagi bayi baru lahir.Banyak penelitian yang membuktikan bahwa Air Susu Ibu merupakan makanan terbaik dan utama bagi bayi karena di dalam ASI terkandung antibodi yang diperlukan bayi untuk melawan penyakit-penyakit yang menyerangnya.ASI sudah diketahui keunggulannya, namun kecenderungan para ibu untuk tidak menyusui bayinya secara eksklusif semakin besar. Hal ini dipengaruhi oleh berbagai macam faktor, antara lain pekerjaan, usia dan pendidikan. Tujuan penelitian ini untuk mengetahui hubungan antara pengetahuan ibu mengenai manfaat ASI pada bayi dengan pemberian ASI eksklusif. Jenis penelitian deskriptif potong lintang dengan metode survei lapangan.Terdapat 80 ibu yang menjadi subjek penelitian. Hasil yang di dapatkan 12 ibu memiliki pengetahuan baik, 39 ibu memiliki pengetahuan cukup, dan 29 ibu memiliki pengetahuan kurang. Yang memberikan ASI eksklusif sebanyak 41 ibu dan yang tidak sebanyak 39 ibu, terdapat hubungan bermakna dengan uji Chi-Square $(p=0,016)$. Simpulan:Semakin tinggi pengetahuan ibu mengenai manfaat ASI pada bayi, semakin tinggi keberhasilan menyusui.
\end{abstract}

Kata kunci. ASI eksklusif, ibu, pengetahuan.

Program Pembangunan Nasional (PROPENAS) mengamanatkan bahwa pembangunan diarahkan pada meningkatnya mutu sumber daya manusia (SDM yang berkualitas). Modal dasar pemben- tukan manusia berkualitas dimulai sejak bayi dalam kandungan disertai dengan pemberian air susu ibu (ASI) sejak usia dini, terutama pemberian ASI eksklusif. ${ }^{1}$

Air Susu Ibu (ASI) merupakan ma- 
kanan bayi yang terbaik dan setiap bayi berhak mendapatkan ASI, maka Departemen Kesehatan telah menerbitkan Surat Keputusan Menteri no.450/MENKES/SK/ IV/2004 tentang Pemberian Air Susu Ibu (ASI) secara eksklusif pada bayi di Indonesia. ${ }^{2}$

Air susu ibu (ASI) adalah makanan terbaik bagi bayi baru lahir, baik bayi yang dilahirkan cukup bulan (matur) maupun kurang bulan (prematur). Berbagai hasil penelitian menunjukan bahwa pemberian ASI memberikan banyak keuntungan fisiologis maupun emosional. World Health Organization (WHO), American Academy of Pediatrics (AAP), American Academy of Family Physicians (AAFP) dan Ikatan Dokter Anak Indonesia (IDAI) merekomendasikan pemberian ASI ekslusif selama enam bulan dan pemberian ASI dilanjutkan sampai dua tahun. ${ }^{3}$

Banyak penelitian yang membuktikan bahwa Air Susu Ibu merupakan makanan terbaik dan utama bagi bayi karena di dalam ASI terkandung antibodi yang diperlukan bayi untuk melawan penyakitpenyakit yang menyerangnya. Pada dasarnya ASI adalah imunisasi pertama karena ASI mengandung bergbagai zat kekebalan antara lain immunoglobulin. ${ }^{4}$

Survey Demografi dan Kesehatan Indonesia (SDKI) 2007 didapatkan data bahwa 95\% balita di Indonesia pernah mendapatkan ASI, 44\% bayi baru lahir mendapat ASI dalam satu jam setelah lahir dan $62 \%$ bayi mendapat ASI pada hari pertama namun hanya $32 \%$ bayi yang mendapatkan ASI ekslusif sampai enam bulan. ${ }^{3}$ Berdasarkan data Riskesdas tahun 2010 menunjukan pemberian ASI di Indonesia saat ini memprihatinkan, bayi yang menyusu eksklusif sampai enam bulan hanya $15,3 \% .^{5}$ Data UNICEF menunjukan sekitar 30 ribu kematian anak balita di Indonesia setiap tahunnya, dan 10 juta kematian balita di seluruh dunia setiap tahunnya, yang sebenarnya dapat dicegah melalui pemberian ASI eksklusif selama enam bulan sejak kelahiran bayi. ${ }^{6}$

Salfinah dalam penelitiannya mengatakan bahwa $75,6 \%$ ibu yang tidak memberikan ASI eksklusif adalah ibu dengan pendidikan tamat SD, dan berstatus sebagai pekerja lepas (buruh). Selain itu $13,33 \%$ ibu yang tidak memberikan ASI eksklusif masih mengemukakan ASI tidak bermanfaat terhadap bayinya serta 23,02\% masih membuang kolostrumnya. Masih rendahnya angka pencapaian ASI eksklusif tentu saja perlu mendapat perhatian karena berkontribusi terhadap rendahnya kualitas sumber daya manusia di masa mendatang serta berdampak pula terhadap tingginya angka kesakitan maupun angka kematian.

Air Susu Ibu (ASI) sudah diketahui keunggulannya, namun kecenderungan para ibu untuk tidak menyusui bayinya secara eksklusif semakin besar. Hal ini dapat dilihat dengan semakin besarnya jumlah ibu menyusui yang memberikan makanan tambahan lebih awal sebagai pengganti ASI. Berbagai alasan dikemukakan oleh ibu-ibu sehingga dalam pemanfaatan ASI secara ekslusif kepada bayinya rendah, antara lain adalah pengaruh iklan/ promosi pengganti ASI, ibu bekerja, lingkungan sosial budaya, pendidikan, pengetahuan yang rendah serta dukungan suami yang rendah $^{8}$

\section{METODE PENELITIAN}

Jenis penelitian ini merupakan suatu penelitian deskriptifcross sectional dengan metode survey lapangan.Populasi dalam penelitian ini adalah semua ibu yang memiliki bayi atau anak yang datang berobat di Irina E, Poliklinik anak dan tumbuh kembang BLU RSUP Prof. dr. R. D. Kandou dan sampelnya ialah ibu yang memiliki bayi/anak yang berumur 6 bulan10 tahun yang datang berobat di Irina E, Poliklinik Anak dan Tumbuh Kembang BLU RSUP Prof. dr. R. D. Kandou. Penelitian ini dilaksanakan pada bulan November-Desember 2012.

\section{HASIL}

Berdasarkan tabel 1 dapat dilihat karakteristik tingkat pengetahuan, dimana dari 80 responden penelitian sebagian besar 
Tabel 1. Distribusi menurut pengetahuan responden.

\begin{tabular}{llll} 
No. & Pengetahuan Responden & N & $\mathbf{\%}$ \\
\hline 1. & Baik & 12 & 15,0 \\
2. & Cukup & 39 & 48,8 \\
3. & Kurang & 29 & 36,3 \\
\hline & Total & 80 & 100 \\
\hline
\end{tabular}

mempunyai pengetahuan cukup dengan jumlah 39 responden (48,8\%), pengetahuan kurang dengan jumlah 29 responden $(36,3 \%)$ dan pengetahuan baik dengan jumlah 12 responden (15\%).

Tabel 2.Distribusi menurut pemberian ASI eksklusif responden.

\begin{tabular}{llll}
\hline No. & \multicolumn{1}{c}{$\begin{array}{c}\text { Pemberian } \\
\text { ASI Eksklusif }\end{array}$} & N & \% \\
\hline 1. & Ya & 41 & 51,2 \\
2. & Tidak & 39 & 48,8 \\
\hline & Total & 80 & 100 \\
\hline
\end{tabular}

Berdasarkan tabel 2 dapat dilihat karakteristik pemberian ASI Eksklusif, dari 80 responden penelitian sebagian besar sudah memberikan ASI Eksklusif dengan jumlah 41 responden (51,2\%) dan yang tidak mem-berikan ASI Eksklusif dengan jumlah 39 responden $(48,8 \%)$.

Berdasarkan tabel 3 dapat dilihat bahwa sebagian besar responden dengan pengetahuan cukup sudah memberikan ASI Eksklusif berjumlah 21 responden (26,3\%) dan yang paling sedikit memberikan ASI Eksklusif berada pada pengetahuan baik dan kurang masing-masing sebanyak 10 responden $(12,3 \%)$, sedangkan responden yang tidak memberikan ASI Eksklusif sebagian besar berada pada pengetahuan baik yang berjumlah dua responden (2,5\%).

\section{BAHASAN}

Hasil penelitan tentang hubungan pengetahuan dengan pemberian ASI eksklusif diperoleh bahwa sebagian besar sudah memiliki pengetahuan yang cukup dalam memberikan ASI Eksklusif sebanyak 21 responden (26,3\%). Hasil uji statistik dengan menggunakan Chi-Square diperoleh nilai $\mathrm{p}=0,016<0,05$, dimana ada hubungan yang signifikan antara pengetahuan dengan pemberian ASI Eksklusif. Sejalan dengan penelitian Elinofia (2011) yang menyatakan ada hubungan antara pengetahuan ibu dengan pemberian ASI Eksklusif. ${ }^{9}$ Notoatmodjo (2003), menjelaskan bahwa pengetahuan apabila ditunjang oleh pendidikan yang baik maka seseorang dapat mengetahui atau memahami sesuatu yang disampaikan atau diinformasikan, pendidikan juga akan menghasilkan perubahan atau peningkatan pengetahuan masyarakat. Dalam penelitian ini ternyata pengetahuan ibu terhadap pemberian ASI Eksklusif baik, lebih besar daripada cukup atau kurang.Hal ini mungkin saja disebabkan keinginan mereka untuk mengetahui sendiri lewat media cetak maupun elektronik. Jadi peneliti merasa bahwa media sangat menunjang program pemerintah terutama masyarakat akan pemberian ASI eksklusif saat ini.Tapi dalam hal pemberian ASI eksklusif, bukan hanya tergantung pada pengetahuan ibu tapi juga tergantung pada banyak hal.

Tabel 3. Hubungan pengetahuan responden dengan pemberian ASI eksklusif.

\begin{tabular}{|c|c|c|c|c|c|c|c|c|}
\hline & \multicolumn{4}{|c|}{ Pemberian ASI Eksklusif } & \multicolumn{2}{|c|}{ Total } & \multirow{2}{*}{$\boldsymbol{P}$} \\
\hline & & Ya & $\%$ & Tidak & $\%$ & Jlh & $\%$ & \\
\hline \multirow{4}{*}{ Pengetahuan } & Baik & 10 & 12,5 & 2 & 2,5 & 12 & 15,0 & \multirow{3}{*}{0,016} \\
\hline & Cukup & 21 & 26,3 & 18 & 22,5 & 39 & 48,8 & \\
\hline & Kurang & 10 & 12,5 & 19 & 23,8 & 29 & 36,3 & \\
\hline & Total & 41 & 51,3 & 39 & 48,8 & 80 & 100 & \\
\hline
\end{tabular}


Umur ibu sangat menentukan kesehatan maternal karena berkaitan dengan kondisi kehamilan, persalinan, dan nifas, serta cara mengasuh juga menyusui bayinya. Ibu yang berumur kurang dari 20 tahun masih belum matang dan belum siap secara jasmani dan sosial dalam menghadapi kehamilan, persalinan, serta dalam membina bayi dalam dilahirkan.Sedangkan ibu yang berumur 20-35 tahun, menurut disebut sebagai "masa dewasa” dan disebut juga masa reproduksi. Pada masa ini diharapkan orang telah mampu untuk memecahkan masalah-masalah yang dihadapi dengan tenang secara emosional, terutama dalam menghadapi kehamilan, persalinan, nifas, dan merawat bayinya nanti.Pada primipara dengan usia 35 tahun ke atas dengan produksi hormon relatif berkurang akan mengakibatkan proses laktasi menurun, sedangkan pada usai remaja (12-19 tahun) harus dikaji pula secara teliti karena perkembangan fisik, psikologis, maupun sosialnya belum siap sehingga dapat mengganggu keseimbangan psikologis dan dapat mempengaruhi dalam produksi ASI. Semakin meningkatnya umur dan tingkat kematangan maka kekuatan seseorang dalam berpikir dan bekerja juga akan lebih matang.

Tingkat pendidikan ibu yang rendah mengakibatkan kurangnya pengetahuan ibu dalam menghadapi masalah, terutama dalam pemberian ASI eksklusif.Pengetahuan ini diperoleh baik secara formal maupun informal.Sedangkan ibu-ibu yang mempunyai tingkat pendidikan yang lebih tinggi, umumnya terbuka menerima perubahan atau hal-hal guna pemeliharaan kesehatannya. Pendidikan juga akan membuat seseorang terdorong untuk ingin tahu mencari pengalaman sehingga informasi yang diterima akan menjadi pengetahuan. Pendidikan adalah upaya persuasif atau pembelajaran kepada masyarakat agar masyarakat mau melakukan tindakan-tindakan atau praktik untuk memelihara (mengatasi masalah) dan meningkatkan kesehatannya. Perubahan atau tindakan pemeliharaan dan peningkatan kesehatan yang dihasilkan oleh pendidikan kesehatan ini didasarkan pengetahuan dan kesadarannya melalui proses pembelajaran sehingga perilaku tersebut diharapkan akan berlangsung lama (long lasting) dan menetap (langgeng) karena didasari oleh kesadaran. Memegang kelemahan dan pendekatan kesehatan ini adalah hasil lamanya memerlukan waktu lama. Pendidikan diperkirakan ada kaitannya dengan pengetahuan ibu menyusui dalam memberikan ASI eksklusif, hal ini dihubungkan dengan tingkat pengetahuan ibu bahwa seseorang yang berpendidikan lebih tinggi akan mempunyai pengetahuan yang lebih luas dibandingkan dengan tingkat pendidikan yang rendah. Pengetahuan paradigma itu dipicu oleh tingginya tingkat kebutuhan hidup dan meningkatnya pemahaman kaum wanita tentang aktualisasi diri. Pendidikan dan kebebasan informasi membuat para wanita masa kini lebih berani memasuki wilayah pekerjaan lain yang dapat memberdayakan kemampuan dirinya secara maksimal sehingga ibu tidak dapat memberikan ASI eksklusif. Pendidikan juga akan membuat seseorang terdorong untuk ingin tahu mencari pengalaman sehingga informasi yang diterima akan jadi pengetahuan. ${ }^{10}$

Penelitian Elinofia (2011), yang menyatakan ada hubungan antara pekerjaan dengan pemberian ASI Eksklusif. Kelompok ibu yang bekerja mengalami dilema dalam memberikan ASI meskipun mereka tahu manfaat dan keunggulan ASI namun sulit untuk mempraktekkannya. Alokasi waktu kerja sehari-hari yang banyak berada di luar rumah dan di tempat bekerja tidak mendukung program pemberian ASI. Pada prinsipnya pemberian ASI dapat diberikan secara langsung dan tidak langsung. Dengan terbukanya kesempatan bekerja dan tuntutan untuk bekerja membantu ekonomi keluarga maka sebagian ibu-ibu memilih bekerja di luar rumah. Dengan bekerja ibu tidak dapat berhubungan penuh dengan bayinya, akibatnya ibu cenderung memberikan susu formula dan diberikan melalui botol, menyebabkan frekuensi penyusuan akan berkurang dan produksi ASI akan menurun. Keadaan ini menyebabkan ibu menghentikan pemberian ASI. Jadi, 
seorang ibu yang bekerja kemungkinan menyusui bayinya secara eksklusif menurun drastis.

\section{SIMPULAN}

1. Sebagian besar responden memiliki pengetahuan yang cukup mengenai manfaat ASI pada bayi.

2. Sebagian besar responden sudah memberikan ASI eksklusif pada bayinya

3. Hasil pengujian statistik dengan menggunakan uji Chi-Square diperoleh nilai $p$ $=0,016$, dengan $\alpha=0,05$, maka nilai $p=$ $0,016<0,05$, sehingga hipotesis alternatif (Ha) diterima dan hipotesis nol (Ho) ditolak. Dengan demikian dapat disimpulkan bahwa ada hubungan antara pengetahuan dengan pemberian ASI Eksklusif.

\section{SARAN}

1. Perlunya dukungan dari keluarga agar ibu tetap memberikan ASI eksklusif pada bayinya.

2. Perlunya peningkatan informasi/promosi tentang pentingnya pemberian ASI eksklusif pada bayi usia 0-6 bulan melalui kegiatan penyuluhan oleh tenagatenaga kesehatan di fasilitas-fasilitas pelayanan kesehatan seperti rumah sakit, puskesmas, posyandu, klinik bersalin, serta organisasi-organisasi yang ada di masyarakat seperti PKK.

\section{DAFTAR PUSTAKA}

1. Roesli U. Mengenal ASI Eksklusif. Edisi ke-3. Jakarta: Trubus Agriwidya, 2005

2. Departemen Kesehatan Republik Indonesia. Profil Kesehatan Indonesia. Jakarta: 2007.

3. Suradi R, Hegar B, Partiwi AN, Marzuki NS, Ananta Y. Indonesia Menyusui. Badan Penerbit IDAI. Jakarta: 2010. hal 108:255-6.

4. Soekirman. Ilmu Gizi Anak.Edisi ke 4. Fakultas Kedokteran Universitas Indonesia. Jakarta: 2006.

5. RISKESDAS, Pemberian ASI Eksklusif pada Bayi Baru Lahir, http://health.detik. com/read/2011/03/29/125146/1603616/746 /hanya-15-persen-bayi-indonesia-yangdiberi-asi-eksklusif.

6. UNICEF, ASI Eksklusif Tekan Angka Kematian Bayi Indonesia, http://situs. kesrepro.info/kia/agu/2006/kia03.htm, diakses tanggal 1 September 2007.

7. Salfina, Elmida. Hubungan Pengetahuan dan Perilaku Ibu Dalam Pemberian ASI Eksklusif di Kecamatan Tebet. Jurnal Kesehatan Masyarakat UI. Jakarta: 2003.

8. Departemen Kesehatan RI. Pedoman Pendampingan Keluarga Menuju Kadarzi. Jakarta: 2007.

9. Elinofia. Hubungan Pendidikan, Pengetahuan, Pekerjaan dan Dukungan Keluarga dengan Pemberian ASI Eksklusif di Puskesmas Sawah Lebar. Bengkulu: 2011

10. Arini H. Mengapa Seorang Ibu Harus Menyusui. Flashbooks. Jakarta: 2012. hal 69. 